\title{
Cariprazine Add-on in Inadequate Clozapine Response: A Report on Two Cases
}

\author{
Domenico De Berardis ${ }^{1,2}$, Gabriella Rapini ${ }^{1}$, Luigi Olivieri ${ }^{1}$, Agostina Giardini ${ }^{1}$, Ida De Lauretis ${ }^{1}$, \\ Nicola Serroni ${ }^{1}$, Laura Orsolini ${ }^{3}$, Michele Fornaro ${ }^{4}$, Felice lasevoli ${ }^{4}$, Sabatino Trotta ${ }^{5}$, Paolo Cottura ${ }^{6}$, \\ Federica Vellante ${ }^{2}$, Marco Alessandrini ${ }^{2}$, Massimo Di Giannantonio ${ }^{2}$ \\ ${ }^{1}$ National Health Service, Department of Mental Health, Psychiatric Service of Diagnosis and Treatment, Hospital "G. Mazzini," Teramo, \\ ${ }^{2}$ Department of Neurosciences and Imaging, Chair of Psychiatry, University "G. d'Annunzio," Chieti, Italy, ${ }^{3}$ School of Life and Medical Sciences, \\ University of Hertfordshire, Hatfield, UK, ${ }^{4}$ Laboratory of Molecular Psychiatry and Psychopharmacotherapeutics, Section of Psychiatry, \\ Department of Neuroscience, University School of Medicine "Federico II," Naples, ${ }^{5}$ National Health Service, Department of Mental Health, \\ Pescara, ${ }^{6}$ National Health Service, Department of Mental Health, Psychiatric Service of Diagnosis and Treatment, Cuneo, Italy
}

Cariprazine is a novel antipsychotic drug that exerts partial agonism of dopamine $D_{2} / D_{3}$ receptors with preferential binding to the $\mathrm{D}_{3}$ receptor, antagonism of $5 \mathrm{HT}_{2 \mathrm{~B}}$ receptors, and partial agonism of $5 \mathrm{HT}_{1 \mathrm{~A}}$. Currently, cariprazine has shown clinical efficacy in patients with schizophrenia and with bipolar disorder, as well as adjunctive treatment in patients with Major Depressive Disorder (MDD) and drug-resistant MDD. In the present case series, we report on two patients with treatment-resistant schizophrenia and partial response to clozapine who benefit from combination with cariprazine. The effects of cariprazine combination were remarkable also concerning the adverse metabolic effects of clozapine.

KEY WORDS: Cariprazine; Clozapine; Effectiveness; Efficacy; Schizophrenia; Tolerability.

\section{INTRODUCTION}

Schizophrenia is a chronic and devastating disease affecting around $0.5 \%$ of the population [1]. It is known that the complete remission or recovery of symptoms is relatively rare in schizophrenia, and the treatment resistance remains one of the most critical challenges in psychiatry [2]. The gold standard in the case of resistant schizophrenia is the clozapine treatment [3]. However, despite the greater efficacy of clozapine over other antipsychotics in the management of resistant schizophrenia, a significant number of patients fail to attain adequate response or develop clozapine-related adverse effects, and clozapine-resistant schizophrenia represents a challenge for

Received: October 22, 2019 / Revised: November 19, 2019 Accepted: November 27, 2019

Address for correspondence: Domenico De Berardis National Health Service, Department of Mental Health, Psychiatric Service of Diagnosis and Treatment, Hospital "G. Mazzini”, piazza Italia 1, Teramo 64100, Italy

E-mail: domenico.deberardis@aslteramo.it ORCID: https://orcid.org/0000-0003-4415-5058 the clinician and a calamity for the patients $[4,5]$.

Cariprazine, also named the "rip" [6], is a novel second-generation antipsychotic with antagonist-partial agonist properties at $D_{2}$ and $D_{3}$ receptors, with preferential binding to the $\mathrm{D}_{3}$ receptors [7]. Cariprazine has been approved by the Food and Drug Administration for the treatment of adult patients with schizophrenia (Europe and USA) and acute treatment of manic/ and mixed episodes of bipolar disorder (only USA) [8,9].

Cariprazine acts as an antagonist or partial agonist at $D_{2} / D_{3}$ receptors, depending on the endogenous dopaminergic tone [10]. At high dopamine levels, it seems to act as an antagonist, while at lower dopamine levels, it exerts its agonist action, by increasing the dopamine receptor activity $[11,12]$. It preferentially has a 5- to 30-fold greater affinity for human $\mathrm{D}_{3}$ receptors $(\mathrm{Ki}=0.085 \mathrm{nM})$ than for the $\mathrm{D}_{2 \mathrm{~L}}(\mathrm{Ki}=0.49 \mathrm{nM})$ and $\mathrm{D}_{2 \mathrm{~S}}(\mathrm{Ki}=0.69 \mathrm{nM})$ [13]. Meanwhile, even though to a more limited extent, cariprazine also shows partial agonism at the $5 \mathrm{HT}_{1 \mathrm{~A}}$ receptors $(\mathrm{Ki}=2.46 \mathrm{nM})$, hence by exerting an anti-

(c) This is an Open-Access article distributed under the terms of the Creative Commons Attribution Non-Commercial License (http://creativecommons.org/licenses/by-nc/4.0) which permits unrestricted non-commercial use, distribution, and reproduction in any medium, provided the original work is properly cited. 
depressant effect in addition to the antipsychotic effect $[14,15]$. Moreover, cariprazine also shows an antagonist at human $5 \mathrm{HT}_{2 \mathrm{~B}}$ receptors $(\mathrm{Ki}=0.58 \mathrm{nM})$, which has a crucial role in modulating dopamine release in the nucleus accumbens [16].

Interestingly, besides the positive effects on positive symptoms, cariprazine is associated with improvements in primary negative symptoms of schizophrenia and these improvements are unlikely to result from improved positive or overall symptoms [17].

In the present paper, we report on two cases of treatment-resistant schizophrenia with inadequate response to clozapine who were successfully treated with cariprazine combination in the outpatient facility of Hospital of Teramo, Italy.

\section{CASE}

\section{Case 1}

She is a 29-year-old unemployed and unmarried woman with a long history of schizophrenia diagnosed when she was 19-year-old with an acute episode characterized by mixed positive and negative symptoms with marked hostility. During the years, she underwent several treatments with both oral (haloperidol, olanzapine, and paliperidone) and long-acting antipsychotics (haloperidol decanoate and aripiprazole long-acting) with no effects on psychopathology. Then, from almost one year, she was switched to clozapine $450 \mathrm{mg} /$ day with an inadequate response, despite a tentative to augment with amisulpride $800 \mathrm{mg} /$ die that was reported ineffective. In fact, at the time of our observation (referred to us by her general practitioner) the patient was symptomatic, and the scores of Positive and Negative Symptoms Scale (PANSS) were still clinically significant (total score $=113$, positive $=22$, negative $=33$, general $=58$ ). Moreover, the patient developed weight gain during clozapine treatment (at the time of our first observation, her body weight was $84 \mathrm{~kg}$, and body mass index [BMI] was $26.8 \mathrm{~kg} / \mathrm{m}^{2}$ ).

Thus, considering the failure of previous treatment with aripiprazole (due to a non response, but without adverse effects), cariprazine combination was offered and introduced at the initial dosage of $1.5 \mathrm{mg}$ in the morning. After a week, cariprazine was titrated to $3 \mathrm{mg} / \mathrm{die}$ without adverse effects. After 30 days of cariprazine combination we observed an improvement in PANSS scores (total score $=89$, positive $=18$, negative $=27$, general $=44$ ) After other three months of therapy, the PANSS scores were remarkably improved (total score $=74$, positive $=$ 14 , negative $=20$, general $=40$ ) without adverse effects reported. Moreover, we noted a significant improvement in weight $(79 \mathrm{~kg})$ and BMI $\left(25.1 \mathrm{~kg} / \mathrm{m}^{2}\right)$.

The last observation was carried out in September 2019, after other four months of combination therapy, and the PANSS scores further improved (total score $=57$, positive $=10$, negative $=14$, general $=33$ ) as well as the BMI $\left(24.6 \mathrm{~kg} / \mathrm{m}^{2}\right)$. The patient found a job as a part-time working in handbag manufacture with a reported good yield and performed a regular and moderate physical activity three times a week. No adverse effects were reported or observed, and the patient was taking $400 \mathrm{mg} /$ day of clozapine and cariprazine $3 \mathrm{mg} /$ day.

The subject gave us written informed consent for publication of this case report.

\section{Case 2}

$\mathrm{He}$ is a 35-year-old blue-collar unmarried man who was diagnosed with schizophrenia at the age of 24-yearold. His onset was accompanied by substance abuse (mainly cocaine and cannabis) and was characterized by positive symptoms, a marked impulse dyscontrol with great hostility and negative symptoms such as blunted affect, social withdrawal, and poor rapport. He was treated in the past with several antipsychotics (haloperidol, olanzapine, and paliperidone long-acting) without response and considerable problem in functioning (the patient lost his job). From almost one year and a half, he was taking clozapine $350 \mathrm{mg} /$ day with a functional improvement only on hostility and uncooperativeness, without significant effects on other symptoms. He was also administered in the past clozapine $400 \mathrm{mg} /$ day, but he developed marked sedation, and the dosage was reduced to $350 \mathrm{mg} /$ day that was well tolerated. He willingly decided to consult us, and at the time of our observation, he was symptomatic, and the scores of PANSS were still clinically significant (total score $=121$, positive $=27$, negative $=34$, general $=$ 70).

Moreover, the patient was overweight even if he was unable to relate this to clozapine treatment (his body weight was $95 \mathrm{~kg}$, and BMI was $28.4 \mathrm{~kg} / \mathrm{m}^{2}$ ). He was offered to introduce aripiprazole, but he refused due to his friend, who was taking it and told him about unknown 
"adverse effects." Then, cariprazine was offered, and he agreed to introduce it at an initial dosage of $1.5 \mathrm{mg} /$ day. After three weeks of therapy, a slight improvement on PANSS was seen (total score $=101$, positive $=20$, negative $=30$, general $=61$ ), and the patient reported that he "felt better" especially on functioning and cognitions without adverse effects. The patient agreed to titrate cariprazine up to $3 \mathrm{mg} /$ day. After other two months we observed an improvement of both PANSS (total score $=77$, positive $=13$, negative $=15$, general $=49)$ and BMI $(26.9$ $\left.\mathrm{kg} / \mathrm{m}^{2}\right)$, and clozapine was reduced to $300 \mathrm{mg} /$ day. The improvement was constant, and he was able to find a job as blue collar in a brick factory as "...my mind and thoughts are more clear...”.

The last observation was conducted in September 2019 after further three months of combination therapy, and the PANSS scores were also improved (total score $=57$, positive $=9$, negative $=12$, general $=29$ ) as well as the BMI $\left(25.6 \mathrm{~kg} / \mathrm{m}^{2}\right)$. No adverse effects were reported or observed, and the patient was taking $300 \mathrm{mg} /$ day of clozapine and cariprazine $3 \mathrm{mg} /$ day.

The subject gave us written informed consent for publication of this case report.

\section{DISCUSSION}

To date, these were the first cases of cariprazine combination with clozapine in the occurrence of inadequate response to the latter. Cariprazine combination showed a remarkable effect, as demonstrated by a reduction in PANSS scores over time.

Even if the decrease in PANSS scores was observed for all subscales, a noticeable reduction was obtained concerning negative symptoms that are in line with the mechanism of action on $\mathrm{D}_{3}$ of cariprazine [18]. The $\mathrm{D}_{3}$ receptors, structurally similar to the $\mathrm{D}_{2}$ receptor, are auto-receptors able to modulate the phasic dopaminergic activity and linked to cognition, mood, emotions and reward/substance abuse [19]. Therefore, some authors support its potential role as a pro-cognitive agent and effective treatment in the management of negative symptoms of schizophrenia and an enhancer of the working memory as well [20]. Several studies have suggested that cariprazine affinity and action on $\mathrm{D}_{3}$ may explain its efficacy on negative symptoms, executive deficits, cognitive and mood impairment $[21,22]$. $\mathrm{D}_{3}$ receptors are identified at the asymmetric synapses at the head of dendritic spines, a localization that is in sharp contrast with $\mathrm{D}_{1}$ and $\mathrm{D}_{2}$ receptors, which are both pre-synaptic or spread all over dendrites and dendritic spines in neurons of the caudate putamen and NAc $[20,23,24]$. Moreover, the high concentration of the $\mathrm{D}_{3}$ receptors in the ventral striatum, as compared to the dorsal part, increases the probability that $\mathrm{D}_{3}$ antagonists may have an antipsychotic action with negligible adverse effects including extrapyramidal side effects and catalepsy [25-27].

Moreover, even though to a more limited extent, cariprazine also shows partial agonism at the $5 \mathrm{HT}_{1 \mathrm{~A}}$ receptors, hence by exerting an antidepressant effect in addition to the antipsychotic effect [28]. These mechanisms may explain the positive impact of the cariprazine-clozapine combination seen in these cases.

It is also possible to hypothesize a pharmacokinetic interaction between cariprazine and clozapine to explain the positive outcome of this combination. Cariprazine primarily undergoes dealkylation, dydroxylation, $\mathrm{N}$-oxidation, and cleavage by CYP3A4 and, to a small degree, by CYP2D6 in hepatic microsomes [29]. Clozapine is mostly metabolized in the liver by the CYP1A2 and CYP1A2 activity is an essential determinant of clozapine dose [30]. Other liver enzymes involved in clozapine metabolism include CYP2D6 and CYP3A4 [31]. As the involvement of CYP3A4 in clozapine metabolism is secondary [32], one may hypothesize that a drug-drug interaction with cariprazine may be unlikely. Unluckily we did not evaluate clozapine blood levels, but none of patients reported symptoms of excessive clozapine dosage. Both patients were administered the maximum tolerated doses of clozapine, and no adverse events were reported.

Besides, we observed a good effect on weight and BMI with a reduction of both parameters with cariprazine combination. This effect may be explained by both cariprazine pro-cognitive action (both of patients started to perform a moderate physical activity) and by the decrease in negative symptoms through the action on $\mathrm{D}_{3}$ receptors [22]. Moreover, cariprazine binds to the $5 \mathrm{HT}_{2 \mathrm{~A}}(\mathrm{Ki}=19$ $\mathrm{nM}$ ) that may be involved in pro-cognitive activity [33] while it has a lower affinity for $5 \mathrm{HT}_{7}(\mathrm{Ki}=111 \mathrm{nM}), 5 \mathrm{HT}_{2 \mathrm{C}}$ $(\mathrm{Ki}=134 \mathrm{nM})$ and $\alpha 1$ receptors, by exerting an antagonist action. Its weak action on these receptors may further explain its good metabolic profile [34]. Concerning cariprazine adverse effects $[12,35]$, post hoc analyses of safe- 
ty data from cariprazine studies in schizophrenia showed a dose-response association for several treatment-emergent adverse events and clinical laboratory values including akathisia, extrapyramidal symptoms, creatine phosphokinase and transaminase elevations, increases in blood pressure, but none of these were observed in our cases.

In conclusion, cariprazine add-on to clozapine showed remarkable and relatively rapid efficacy in the treatment of subjects with inadequate response to clozapine. The tolerability of this association was excellent without reported adverse effects. However, future studies on larger samples are needed to elucidate this positive effect better.

\section{- Conflicts of Interest}

No potential conflict of interest relevant to this article was reported.

\section{Author Contributions}

All the Authors contributed to this case series with equal efforts.

\section{ORCID}

Domenico De Berardis

https://orcid.org/0000-0003-4415-5058

Laura Orsolini https://orcid.org/0000-0002-6882-3770

Michele Fornaro https://orcid.org/0000-0002-9647-0853

Felice lasevoli https://orcid.org/0000-0002-7051-5013

Marco Alessandrini https://orcid.org/0000-0002-2821-4620

Massimo Di Giannantonio

https://orcid.org/0000-0001-9681-8058

\section{REFERENCES}

1. Galderisi S, Rucci P, Kirkpatrick B, Mucci A, Gibertoni D, Rocca $\mathrm{P}$, et al. Interplay among psychopathologic variables, personal resources, context-related factors, and real-life functioning in individuals with schizophrenia: a network analysis. JAMA Psychiatry 2018;75:396-404.

2. Iasevoli F, Giordano S, Balletta R, Latte G, Formato MV, Prinzivalli $\mathrm{E}$, et al. Treatment resistant schizophrenia is associated with the worst community functioning among severely-ill highly-disabling psychiatric conditions and is the most relevant predictor of poorer achievements in functional milestones. Prog Neuropsychopharmacol Biol Psychiatry 2016;65:34-48.

3. De Berardis D, Serroni N, Campanella D, Olivieri L, Marini S, Moschetta FS, et al. Safety and efficacy of combined clozapine-azathioprine treatment in a case of resistant schizophrenia associated with Behçet's disease: a 2-year follow-up.
Gen Hosp Psychiatry 2013;35:213.e9-213.e11.

4. De Berardis D, Fornaro M, Anastasia A, Vellante F, Valchera A, Cavuto $\mathrm{M}$, et al. When clozapine fails: augmentation strategies in the management of clozapine-resistant schizophrenia. In: Kim YK, editor. Treatment resistance in psychiatry: risk factors, biology, and management. Singapore:Springer;2019. p.349-367.

5. De Berardis D, Rapini G, Olivieri L, Di Nicola D, Tomasetti C, Valchera A, et al. Safety of antipsychotics for the treatment of schizophrenia: a focus on the adverse effects of clozapine. Ther Adv Drug Saf 2018;9:237-256.

6. Stahl SM. Mechanism of action of cariprazine. CNS Spectr 2016;21:123-127.

7. Misiak B, Bieńkowski P, Samochowiec J. Cariprazine - a novel antipsychotic drug and its place in the treatment of schizophrenia. Psychiatr Pol 2018;52:971-981.

8. Chhatlani A, Farheen SA, Setty MJ, Tampi RR. Use of cariprazine in psychiatric disorders: a systematic review. Ann Clin Psychiatry 2018;30:326-334.

9. McCormack PL. Cariprazine: first global approval. Drugs 2015;75:2035-2043.

10. Laszlovszky I, Kiss B, Barabassy A, Kapas M, Nemeth G. [Cariprazine, a new type - dopamine $D_{3}$ receptor preferring partial agonist atypical antipsychotic for the treatment of schizophrenia and the primary negative symptoms]. Neuropsychopharmacol Hung 2019;21:103-118.

11. Tóth M, Varrone A, Steiger C, Laszlovszky I, Horváth A, Kiss B, et al. Brain uptake and distribution of the dopamine $D_{3} / D_{2}$ receptor partial agonist [11 Clcariprazine: an in vivo positron emission tomography study in nonhuman primates. Synapse 2013;67:258-264.

12. Corponi F, Fabbri C, Bitter I, Montgomery S, Vieta E, Kasper S, et al. Novel antipsychotics specificity profile: a clinically oriented review of lurasidone, brexpiprazole, cariprazine and lumateperone. Eur Neuropsychopharmacol 2019;29:971-985.

13. Citrome L. Cariprazine: chemistry, pharmacodynamics, pharmacokinetics, and metabolism, clinical efficacy, safety, and tolerability. Expert Opin Drug Metab Toxicol 2013;9:193-206.

14. Ragguett RM, McIntyre RS. Cariprazine for the treatment of bipolar depression: a review. Expert Rev Neurother 2019;19: 317-323.

15. De Berardis D, Vellante F, Fornaro M, Orsolini L, Valchera A, Baroni $\mathrm{G}$, et al. Rapid improvement of obsessive-compulsive disorder associated with schizophrenia with cariprazine add-on in a subject under paliperidone long-acting injection: a case report. Int Clin Psychopharmacol 2019. doi: 10.1097/YIC. 0000000000000284. [Epub ahead of print]

16. De Berardis D, Orsolini L, lasevoli F, Prinzivalli E, de Bartolomeis A, Serroni N, et al. The novel antipsychotic cariprazine (RGH-188): state-of-the-art in the treatment of psychiatric disorders. Curr Pharm Des 2016;22:5144-5162.

17. Orsolini L, lasevoli F, Prinzivalli E, Valchera A, Fornaro M, Vecchiotti R, et al. Cariprazine (RGH-188): a new pharmaco- 
logical target option for the treatment of schizophrenia, bipolar disorders and depression? Minerva Psichiatr 2017;58:17-25.

18. Huang M, He W, Kiss B, Farkas B, Adham N, Meltzer HY. The role of dopamine $D 3$ receptor partial agonism in cariprazineinduced neurotransmitter efflux in rat hippocampus and nucleus accumbens. J Pharmacol Exp Ther 2019;371:517-525.

19. Gründer G. Cariprazine, an orally active $D_{2} / D_{3}$ receptor antagonist, for the potential treatment of schizophrenia, bipolar mania and depression. Curr Opin Investig Drugs 2010;11: 823-832.

20. Calabrese F, Tarazi FI, Racagni G, Riva MA. The role of dopamine $D_{3}$ receptors in the mechanism of action of cariprazine. CNS Spectr 2019:1-9.

21. Zhao MJ, Qin B, Wang JB, Zhang YP, Zhao JT, Mao YG, et al. Efficacy and acceptability of cariprazine in acute exacerbation of schizophrenia: meta-analysis of randomized placebo-controlled trials. J Clin Psychopharmacol 2018;38: 55-59.

22. Fleischhacker W, Galderisi S, Laszlovszky I, Szatmári B, Barabássy Á, Acsai K, et al. The efficacy of cariprazine in negative symptoms of schizophrenia: Post hoc analyses of PANSS individual items and PANSS-derived factors. Eur Psychiatry 2019;58:1-9.

23. Frank A, Kiss DJ, Keserü GM, Stark H. Binding kinetics of cariprazine and aripiprazole at the dopamine $D_{3}$ receptor. Sci Rep 2018;8:12509.

24. Werner FM, Coveñas R. Safety of antipsychotic drugs: focus on therapeutic and adverse effects. Expert Opin Drug Saf 2014;13:1031-1042.

25. Moritz AE, Free RB, Sibley DR. Advances and challenges in the search for $D_{2}$ and $D_{3}$ dopamine receptor-selective compounds. Cell Signal 2018;41:75-81.

26. Stahl SM. Drugs for psychosis and mood: unique actions at $D_{3}, D_{2}$, and $D_{1}$ dopamine receptor subtypes. CNS Spectr
2017;22:375-384.

27. Werner FM. Neural networks in neurological and psychiatric diseases. Curr Pharm Des 2019;25:374-375.

28. Herman A, El Mansari M, Adham N, Kiss B, Farkas B, Blier P. Involvement of 5-HT $T_{1 A}$ and 5-HT $T_{2 A}$ receptors but not $\alpha_{2}$-adrenoceptors in the acute electrophysiological effects of cariprazine in the rat brain in vivo. Mol Pharmacol 2018;94: 1363-1370.

29. Nakamura T, Kubota T, Iwakaji A, Imada M, Kapás M, Morio Y. Clinical pharmacology study of cariprazine (MP-214) in patients with schizophrenia (12-week treatment). Drug Des Devel Ther 2016;10:327-338.

30. Thorn CF, Müller DJ, Altman RB, Klein TE. PharmGKB summary: clozapine pathway, pharmacokinetics. Pharmacogenet Genomics 2018;28:214-222.

31. Schoretsanitis G, Kane JM, Ruan CJ, Spina E, Hiemke C, de Leon J. A comprehensive review of the clinical utility of and a combined analysis of the clozapine/norclozapine ratio in therapeutic drug monitoring for adult patients. Expert Rev Clin Pharmacol 2019;12:603-621.

32. Tóth K, Csukly G, Sirok D, Belic A, Kiss Á, Háfra E, et al. Potential role of patients' CYP3A-status in clozapine pharmacokinetics. Int J Neuropsychopharmacol 2017;20:529-537.

33. Barnes SA, Young JW, Markou A, Adham N, Gyertyán I, Kiss $\mathrm{B}$. The effects of cariprazine and aripiprazole on PCP-induced deficits on attention assessed in the 5-choice serial reaction time task. Psychopharmacology (Berl) 2018;235:1403-1414.

34. Halaris A, Wuest J. Metabolic syndrome reversal with cariprazine. J Clin Psychopharmacol 2019;39:413-416.

35. Nasrallah HA, Earley W, Cutler AJ, Wang Y, Lu K, Laszlovszky $\mathrm{I}$, et al. The safety and tolerability of cariprazine in long-term treatment of schizophrenia: a post hoc pooled analysis. BMC Psychiatry 2017;17:305. 